Article

\title{
The Long-Term Hydrological Performance of Permeable Pavement Systems in Northern Spain: An Approach to the "End-of-Life" Concept
}

\author{
Luis A. Sañudo-Fontaneda ${ }^{1,2, *(\mathbb{D})}$, Valerio C. Andres-Valeri ${ }^{3}{ }^{(\mathbb{D})}$, Carlos Costales-Campa ${ }^{1}$, \\ Iñigo Cabezon-Jimenez ${ }^{3}$ and Fernando Cadenas-Fernandez ${ }^{1}$ \\ 1 Department of Construction and Manufacturing Engineering, Polytechnic School of Mieres, \\ University of Oviedo, Calle Gonzalo Gutiérrez Quirós s/n, 33600 Mieres, Spain; \\ UO231116@uniovi.es (C.C.-C.); UO232164@uniovi.es (F.C.-F.) \\ 2 Centre for Agroecology, Water and Resilience (CAWR), Coventry University, Ryton Gardens, Wolston Lane, \\ Coventry CV8 3LG, UK \\ 3 GITECO Research Group, School of Civil Engineering, University of Cantabria, Avenida de los Castros, \\ 39005 Santander, Spain; andresv@unican.es (V.C.A.-V.); iigo.cabezon@alumnos.unican.es (I.C.-J.) \\ * Correspondence: sanudoluis@uniovi.es; Tel.: +34-985-45-81-96
}

Received: 28 February 2018; Accepted: 15 April 2018; Published: 17 April 2018

\begin{abstract}
Porous mixtures and Interlocking Concrete Block Pavements (ICBP) are the most widely used surfaces in Permeable Pavement Systems (PPS). Despite the fact that there are many studies based on the hydrological performance of PPS, there are few long-term studies that identify the end of life of PPS regarding their hydrological performance. A field study has been developed over 10 years in the experimental car park "Las Llamas" in the city of Santander, Northern Spain. Permeability was measured in 37 car park bays (nine Polymer-Modified Porous Concrete, nine Porous Asphalt, and 17 ICBP of two different designs). Tests were conducted under the Spanish Standard NLT-327/00 for the porous-mixture surfaces and the ASTM methods C1701/C1701M-17a and C1781/C1781M-15 for porous mixtures and ICBP, respectively. No maintenance was carried out in this car park since it was opened to traffic in 2008, allowing for the assessment and identification of the hydrological failure of each surface. The research showed that after 10 years of operation without maintenance, the bays constructed using porous mixtures were completely clogged, reaching the end of their operational life after nine years. However, ICBP maintained high infiltration rates, showing better resilience to sediment clogging. Further research is needed to confirm the evolution of ICBP surfaces.
\end{abstract}

Keywords: clogging; concrete blocks; field study; monitoring; porous concrete; porous asphalt; permeameter; resilience; Sustainable Drainage Systems; Stormwater Best Management Practices

\section{Introduction}

Permeable Pavement Systems (PPS), also known as Pervious Pavements [1], are among the most common Sustainable Drainage Systems (SuDS) in the world, having been implemented under all kinds of climatic conditions [2,3]. PPS have been extensively investigated since the beginning of the 21 st century, representing $17.1 \%$ out of total publications on Green Stormwater Infrastructure (GSI) [4], which clearly shows their influence and applicability within the wide range of SuDS techniques available.

PPS are mostly implemented in car parks, private driveways, ports and pedestrian areas, amongst others [5]. PPS are defined based on their surface as porous pavements and permeable pavements, and the difference between them lies in how the runoff infiltrates-across the entire surface material, in the case of a porous pavement, or through an impermeable material placed under a permeable 
disposition [6]. It has been reported by [7] that the most used surfaces in PPS since 1984 were: Pervious Concrete-PC (61\%), Interlocking Concrete Block Pavements-ICBP (17\%) and Porous Asphalt-PA $(16 \%)$.

Many practitioners and academics agree to affirm that sediment clogging is the major threat to the adequate performance of a PPS because it reduces its infiltration capacity, affecting the surface layer to a larger degree than other layers from the PPS structure [8-10].

The failure of a SuDS technique to perform one of its functions has been defined as its "end-of-life" or, in other words, the end of its operational life [11]. When referring to the hydrological performance of a PPS, the "end-of-life" concept can be described as the failure of the surface layer to infiltrate runoff.

There are many tests that have been developed over the years to assess the hydrological performance of a PPS surface. Thus, a wide range of devices have been utilised in the field so far, such as single-ring infiltrometers [12], double-ring infiltrometers [13], and the LCS (its Spanish acronym, from Laboratorio de Caminos de Santander) permeameter [14,15].

Standardised tests are preferable to assess the hydrological performance of PPS and to determine when an "end-of-life" scenario occurs due to their inherent capacity to be used across the world and, therefore, to obtain comparable results.

The main aim of this research is to describe the hydrological performance of a PPS car park by means of its resilience to sediment clogging. With this aim, the reduction of the infiltration capacity was studied through the permeability loss of each car park bay. Trends have been developed in order to identify the "end-of-life" of each PPS surface analysed in this study and when maintenance may be needed to recover permeability and the hydrological functionality of the PPS.

\section{Materials and Methods}

\subsection{Location and Climatic Conditions}

The experimental site of "Las Llamas" is a car park located in the city of Santander, Northern Spain. Santander has a Cfb climate (warm temperature, fully humid and warm summer) based on the Köppen-Geiger classification for world climates [16], with an average annual temperature of $15^{\circ} \mathrm{C}$ and $1136 \mathrm{~mm}$ rainfall [17]. Northern Spain presents the highest average number of days with rainfall events above $1 \mathrm{~mm}$ in the country (125-150 days/year) [18].

\subsection{Materials}

There are 45 watertight car park bays, independent from each other, in the experimental area; this was one of the largest monitored car parks made out of PPS in the world when it was built and opened in 2008 [17]. Metallic plates are utilised to separate each car park bay from the others and from impervious areas. This car park has been heavily used since it was opened to traffic in 2008, being fully occupied by cars between 09:00 a.m. and 6:00 p.m. roughly, from Monday to Friday all through the year, except in July and August. The pattern over the weekend is different, presenting low occupation rates, except for weekends when there are football or basketball games at the nearby football stadium and sports hall. In any case, the continuous presence of cars has had an influence on its operational life, as demonstrated by [19].

The study area consists of 37 car park bays utilising porous mixtures and ICBP; the surfaces were designed and constructed to receive direct rainfall for research purposes at that time. The approximate impervious/permeable ratio for each surface is 1:1. However, it is important to remark that runoff from impervious areas drained towards conventional drainage systems and not towards the permeable pavement bays in all cases, which influences the sediment deposition patterns and thus the clogging processes. Polymer-Modified Porous Concrete (PMPC) was utilised as the surface layer in nine parking bays with $80 \mathrm{~mm}$ depth, whilst nine other parking bays had $80 \mathrm{~mm}$ depth PA, and the remaining 17 bays had ICBP as a surface layer with two different designs ( $80 \mathrm{~mm}$ and $100 \mathrm{~mm}$ depth). All the experimental bays were $4.2 \mathrm{~m}$ long and $2.4 \mathrm{~m}$ wide (Figure 1), representing a permeable area of 
$10 \mathrm{~m}^{2}$ / bay. Thus, the PMPC surface had a total of $90 \mathrm{~m}^{2}$ in the car park, whilst PA had $90 \mathrm{~m}^{2}$ and ICBP $170 \mathrm{~m}^{2}$.

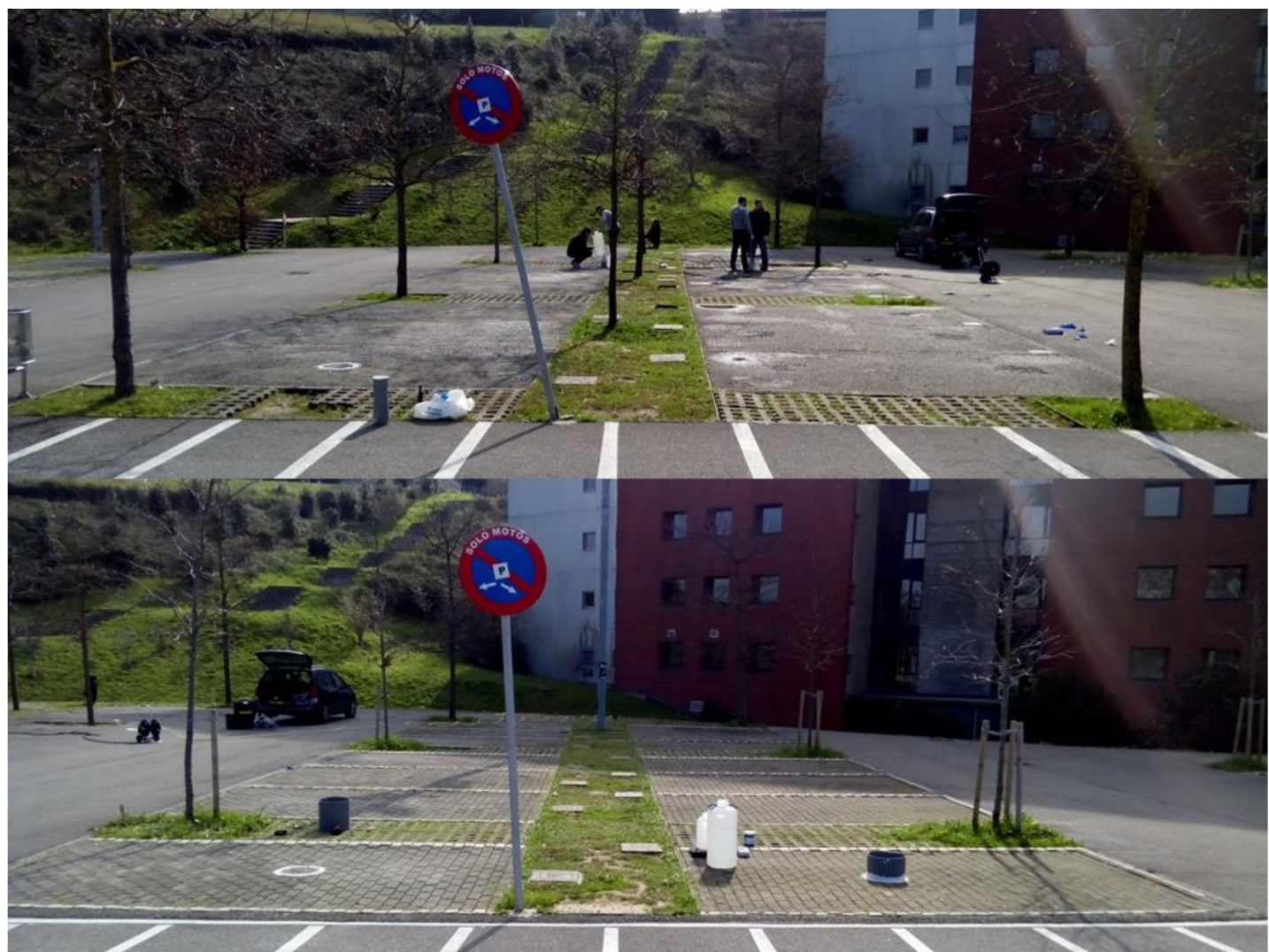

Figure 1. Car park bays subjected to the experiment between 2008 and 2018: upper image, PMPC (left), PA (right); lower image, ICBP-1 (left) and ICBP-2 (right).

The materials used in these 37 car park bays represented a wide range of PPS structures utilised across the world, which makes this study highly comparable with other research (Table 1).

Table 1. PPS structure in the 37 car park bays.

\begin{tabular}{ccccc}
\hline \multirow{2}{*}{ Layer } & \multicolumn{4}{c}{ Type of Surface } \\
\cline { 2 - 5 } & PMPC & PA & ICBP-1 & ICBP-2 \\
\hline Surface & $80 \mathrm{~mm}$ & $80 \mathrm{~mm}$ & $80 \mathrm{~mm}$ & $100 \mathrm{~mm}$ \\
\hline \multirow{2}{*}{ Base } & & Clean limestone aggregates $(50 \mathrm{~mm})$ & \\
\hline \multirow{2}{*}{ Geotextile } & Polyfelt TS30 (4 bays) & Polyfelt TS30 (4 bays) & Inbitex (4 bays) & Polyfelt TS30 (4 bays) \\
& Danofelt PY150 (4 bays) & Danofelt PY150 (4 bays) & One-Way (4 bays) & Danofelt PY150 (4 bays) \\
\cline { 2 - 5 } & Without geotextile (bay1) & Without geotextile (bay1) & Without geotextile (2 bays) & Without geotextile (1 bay) \\
\hline Sub-base & & \multicolumn{2}{c}{ Clean limestone aggregates (350 mm) } \\
\hline
\end{tabular}

The specifications and characteristics of the surface materials used in the study are presented in the following subsection.

\subsubsection{PMPC}

The PMPC surface was $80 \mathrm{~mm}$ thick and its main characteristics are described as follows:

- Compressive strength: 18 and $27 \mathrm{MPa}$ of compressive strength measured according to European Standards [20-22] after seven and 28 days, respectively. 
- Voids: $25.0 \%$.

- Apparent density: 1778 kg/m

The mix design used for this material was that described in [23].

2.2.2. PA

The PA used for this research has the following main characteristics:

- Voids: $23.5 \%$.

- Apparent density: $2050 \mathrm{~kg} / \mathrm{m}^{3}$.

The particle size distribution used to develop this PA was developed according to the European Normative EN 933-1 [24] and the mix design corresponds to that known as PA-12 according to the Spanish standards [25].

\subsubsection{ICBP-1}

The ICBP-1 corresponds to the British design Aquaflow ${ }^{\circledR}$ by Hanson Formpave (Gloucestershire, UK). Each paving unit weights $3.5 \mathrm{~kg}$ and is made out of precast concrete of an impervious material with a $200 \mathrm{~mm} \times 100 \mathrm{~mm}$ rectangular shape and $80 \mathrm{~mm}$ thick. Its tensile splitting strength is in accordance with BS EN 1338:2003 [26] and its initial permeability is $9000 \mathrm{~mm} / \mathrm{h}$.

\subsubsection{ICBP-2}

The ICBP-2 design corresponds to the Spanish "Bloques Monserrat". These concrete paving blocks are conformed by precast concrete of impervious material with a $200 \mathrm{~mm} \times 100 \mathrm{~mm}$ rectangular shape and $100 \mathrm{~mm}$ thick. Each paving unit weights $4.5 \mathrm{~kg}$ and has six elliptical slots for a $6-\mathrm{cm}^{2}$ open area that permits the passage of runoff. There are no aggregates placed between paver joints in this design, which augments the volume of water that can infiltrate towards the lower layers of the PPS.

\subsection{Monitoring Methods Used in the Field}

Permeability tests were carried out in order to monitor the reduction of the infiltration capacity over the years at four main times in the case of the porous mixtures $(0,5,8$ and 10 years), whilst in the case of the ICBP designs, two main times were selected ( 0 and 10 years). PPS car parks are usually designed to have an operational life of 20-25 years. Therefore, the time selected to assess the permeability was considered to be representative of the initial life of the PPS, a quarter-way operational life and half-way operational life.

The central zone of each car park bay (number 5 in Figure 2) was taken as a reference to measure the permeability as it was previously found that the middle part of the bay was that of higher infiltration capacity in this experimental site [19]. In addition to this, eight extra points were measured at the porous-mixture surfaces with the aim of identifying potential differences in the hydrological performance of each bay due to the car parking, as was found by [19] (Figure 2).

\subsubsection{Spanish NLT-327/00}

This Spanish Standard Method [27] was conceived to determine the permeability of in-place porous asphalt pavements. This test can be utilised to determine the permeability of pervious concrete surfaces due to their similar structure of voids, having been used with this aim in mind by previous studies [14,19]. This test is in accordance with the European Standard EN 12697-40 [28].

The standardised device used in this test is the LCS Permeameter (Figure 3). 


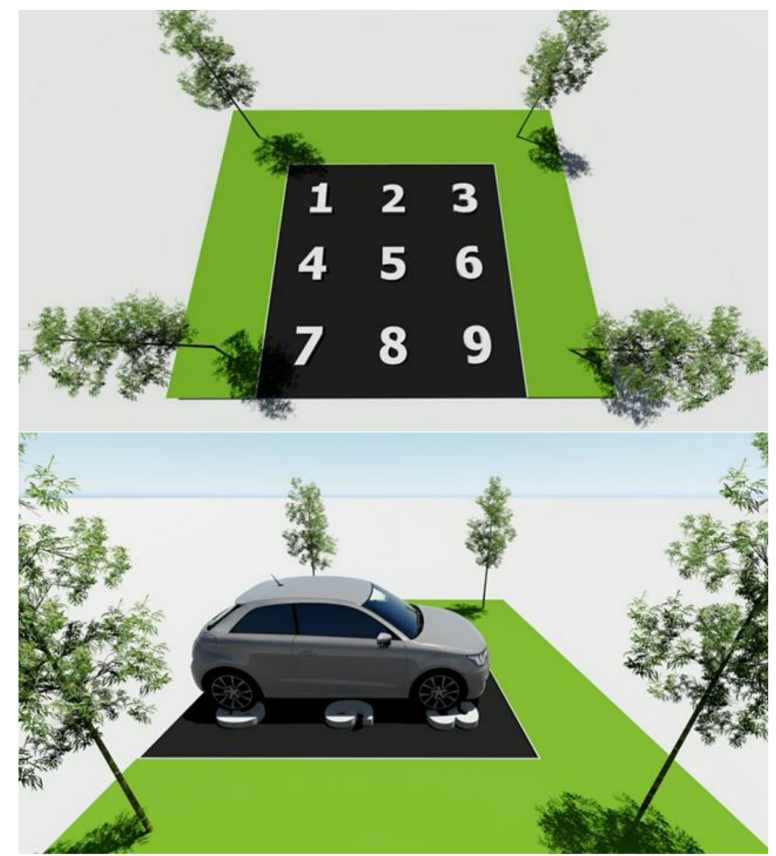

Figure 2. Numbering system for the zones in each car park bay where tests were performed and the common position of a car parked in the bay.

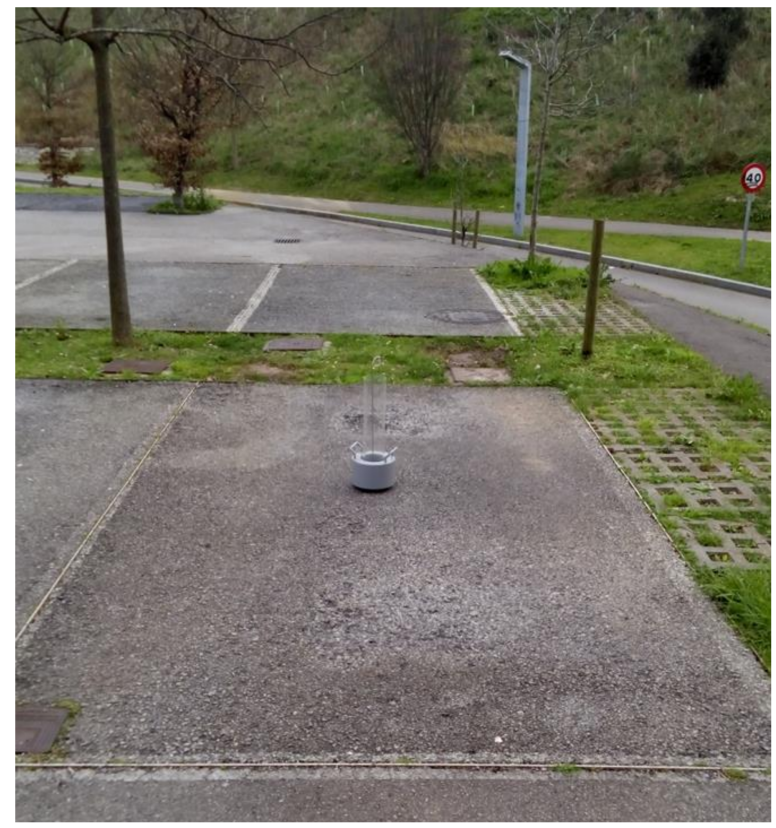

Figure 3. LCS Permeameter ready to begin the NLT-327/00 test on porous-mixture surfaces.

The experimental procedure consists of the following steps:

1. LCS Permeameter. The device was placed at the point where the test was going to be developed, placing the weight on top of the LCS base.

2. Pre-wetting. Water was poured into the LCS up to $15 \mathrm{~cm}$ over the upper mark. Then, the water was allowed to infiltrate in order to saturate the pavement.

3. Testing. Water is poured into the LCS again up to the same point from the pre-wetting and measurements are taken of the time until the level of the water reach the lower mark of the device. 
The result from this test is the time, measured in seconds. The Standard also indicates that there is a relationship between the permeability and the time recorded for PA in the laboratory, which could be extrapolated to this study in the field.

The permeability was obtained by using the following equation:

$$
\ln \mathrm{K}=7.624-1.348 \times \ln t
$$

where

$\mathrm{K}=$ Permeability, $\mathrm{cm} / \mathrm{s} \times 10^{-2}$,

$t=$ time required for measured amount of water to infiltrate the surface between the upper and lower marks of the LCS, s.

\subsubsection{ASTM C1701/C1701M-17a}

This Standard Test Method [29] was developed by the ASTM in order to determine the field water infiltration rate of in-place pervious concrete. In the case of the current research, this test was performed in both PMPC and PA surfaces, due to their similar nature as porous mixtures, for a total of 18 car park bays.

The Infiltration Ring (Figure 4) is the apparatus used to perform this test. This field device must be watertight and rigid and shall have a diameter of $300 \pm 10 \mathrm{~mm}$ with a minimum height of $50 \mathrm{~mm}$. In the case of this study, a PVC tube $310 \mathrm{~mm}$ diameter and $300 \mathrm{~mm}$ height was used.

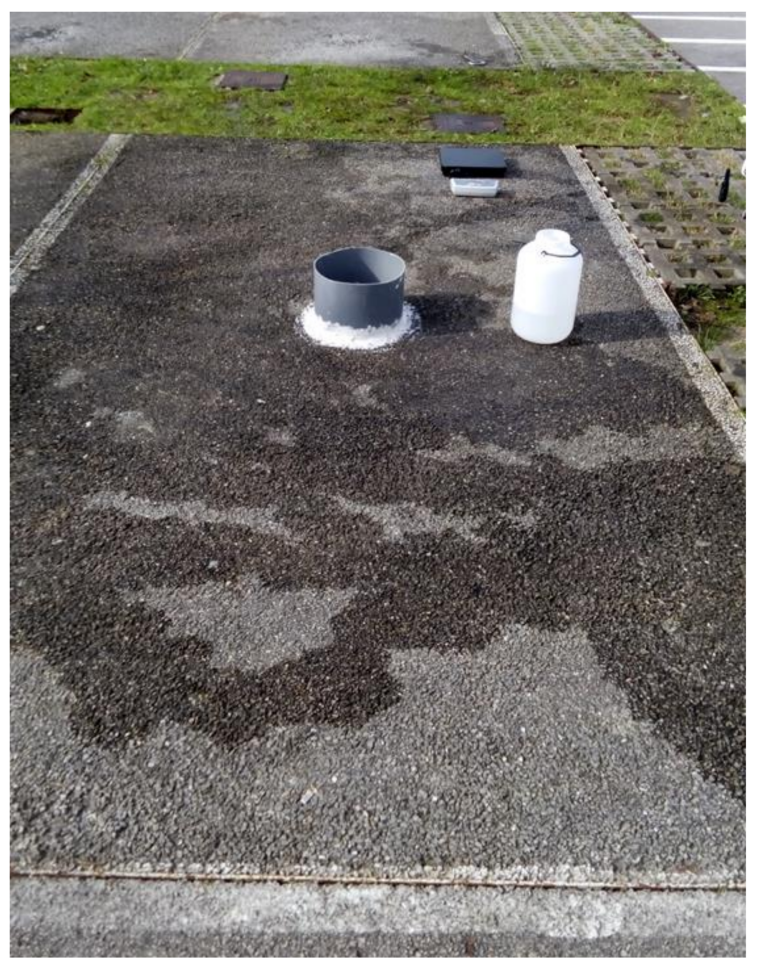

Figure 4. Preparation of the infiltration ring for the ASTM C1701/C1701M-09 test on PMPC and PA surfaces.

The experimental procedure consists of the following steps:

4. Infiltration ring installation. The pavement surface was cleaned and plumber's putty was applied around the bottom edge of the infiltration ring in order to seal its perimeter. 
5. Pre-wetting: $3.60 \mathrm{~kg}$ of water were poured into the ring, maintaining a constant head of water between 100 and $150 \mathrm{~mm}$ from the pavement surface. We measured the time taken between the water coming into contact with the surface and it fully infiltrating the pavement.

6. Test. The test started within $2 \mathrm{~min}$ after the pre-wetting stage; $3.60 \mathrm{~kg}$ of water were utilized again when the elapsed time measured during the pre-wetting stage was above $30 \mathrm{~s}$. Otherwise, $18.00 \mathrm{~kg}$ were poured into the ring. The time was recorded following the same procedure indicated in the previous step.

The permeability was obtained by the following equation:

$$
\mathrm{I}=\frac{\mathrm{K} \times \mathrm{M}}{\mathrm{D}^{2} \times \mathrm{t}}
$$

where

$\mathrm{I}=$ Infiltration rate, $\mathrm{mm} / \mathrm{h}$,

$\mathrm{M}=$ Mass of infiltrated water, $\mathrm{kg}$,

$\mathrm{D}=$ Inside diameter of infiltration ring, $\mathrm{mm}$,

$\mathrm{t}=$ time required for measured amount of water to infiltrate the surface, $\mathrm{s}$,

$\mathrm{K}=$ constant value $4,583,666,000$ in SI units.

\subsubsection{ASTM C1781/C1781M-15}

This Standard Test Method [30] provides the field surface infiltration rate of in-place permeable unit pavement systems with solid interlocking concrete blocks paving units such as the two ICBP designs used in this research (ICBP-1 and ICBP-2). These tests were therefore performed in both ICBP designs for a total of 19 car park bays (Figure 5).

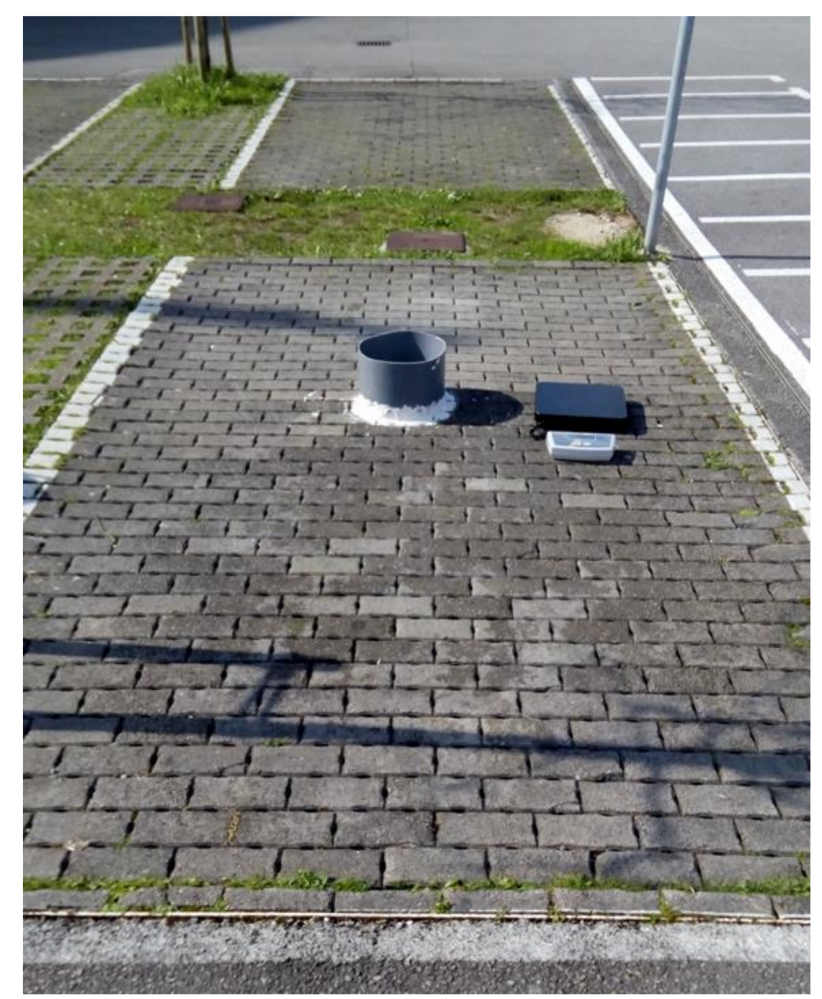

Figure 5. Setup of the infiltration ring for the ASTM C1781/C1781M-15 test on the ICBP surfaces. 
The test followed the same steps described in the ASTM C1701/C1701M-09 standard test (Section 2.3.2) and the permeability was calculated using Equation (2).

\section{Results and Discussions}

\subsection{Hydrological Performance-Field Monitoring Results}

\subsubsection{Permeability Recorded at Year 0}

The first data recorded from the car park were the permeability of the porous mixtures obtained using the LCS permeameter under the Spanish Standards (Table 2). No reliable method under the Spanish Standards was found to obtain the permeability of the ICBP surfaces at that time. Nevertheless, industrial specifications for the ICBP-1 and the ICBP-2 showed a permeability of $9000 \mathrm{~mm} / \mathrm{h}$ and 36,000 , respectively, when built.

Table 2. Newly built permeability values for the porous-mixture surfaces.

\begin{tabular}{ccccc}
\hline \multirow{2}{*}{ Test Used } & \multicolumn{4}{c}{ Average Permeability $(\mathbf{m m} / \mathbf{h})$} \\
\cline { 2 - 5 } & $\begin{array}{c}\text { PMPC } \\
\text { (9 bays) }\end{array}$ & $\begin{array}{c}\text { PA } \\
\text { (9 bays) }\end{array}$ & $\begin{array}{c}\text { ICBP-1 } \\
\text { (10 bays) }\end{array}$ & $\begin{array}{c}\text { ICBP-2 } \\
\text { (9 bays) }\end{array}$ \\
\hline NLT-327/00 & 24,480 & 12,312 & 9000 & 36,000 \\
\hline
\end{tabular}

\subsubsection{Permeability Recorded after Five Years}

The permeability recorded in the experimental site after five years was obtained using the LCS permeameter under the Spanish Standards for porous mixtures [27]. Eighty-one points were measured on each porous mixture surface, nine per car park bay (Figure 2). The average values of permeability can be seen in Table 3.

No reliable method under the Spanish Standards was found to obtain the permeability of the ICBP surfaces at the time.

Table 3. Permeability values for the porous-mixture surfaces after five years of operation.

\begin{tabular}{ccccc}
\hline \multirow{2}{*}{ Test Used } & \multicolumn{4}{c}{ Average Permeability (mm/h) } \\
\cline { 2 - 5 } & $\begin{array}{c}\text { PMPC } \\
\text { (9 bays) }\end{array}$ & $\begin{array}{c}\text { PA } \\
\text { (9 bays) }\end{array}$ & $\begin{array}{c}\text { ICBP-1 } \\
\text { (10 bays) }\end{array}$ & $\begin{array}{c}\text { ICBP-2 } \\
\text { (9 bays) }\end{array}$ \\
\hline NLT-327/00 & 3096 & 1872 & - & - \\
\hline
\end{tabular}

Permeability was significantly different between both porous-mixture surfaces after five years $(p<0.05)$. Both porous surfaces lost permeability at a similar rate during the first five years $(p<0.05)$. Despite the drastic decrease in permeability values after five years in the PMPC surfaces, the values are still high based on the scores given by [31]. However, PA surfaces decreased from a high permeability score down to a medium one [31].

It was found that the zoning described in Figure 2 significantly influenced the permeability in the PMPC surface, though not producing significant differences in the PA surface [19]. Therefore, porous-mixture surfaces that used PMPC were liable to lose their infiltration capacity due to a static vehicle load.

\subsubsection{Permeability Recorded after Eight Years}

The permeability after eight years was obtained using the LCS permeameter under the Spanish Standards for porous mixtures [27]. Eighty-one points were measured on each porous mixture surface, following the same procedure as that used after five years (Section 3.1.2). The average values of permeability can be seen in Table 4 . 
Table 4. Permeability values for the porous-mixture surfaces after eight years of operation.

\begin{tabular}{ccccc}
\hline \multirow{2}{*}{ Test Used } & \multicolumn{4}{c}{ Average Permeability (mm/h) } \\
\cline { 2 - 5 } & $\begin{array}{c}\text { PMPC } \\
\text { (9 bays) }\end{array}$ & $\begin{array}{c}\text { PA } \\
\text { (9 bays) }\end{array}$ & $\begin{array}{c}\text { ICBP-1 } \\
\text { (10 bays) }\end{array}$ & $\begin{array}{c}\text { ICBP-2 } \\
\text { (9 bays) }\end{array}$ \\
\hline NLT-327/00 & 612 & 432 & - & - \\
\hline
\end{tabular}

The same analytical and statistical approach was taken after eight years (Section 3.1.2) [19]. No significant differences were found between zones (Figure 2$)$ after eight years $(p<0.05)$ due to the important loss of permeability, which averaged all values down to a low infiltration capacity near the hydrological "end-of-life" concept. Only the central zone (5 in Figure 2) maintained a significantly different value. This followed on from what was found by [19] after five years of operation.

\subsubsection{Permeability Recorded after 10 Years}

The permeability recorded at the experimental site was obtained by performing the tests developed for each type of surface and can be seen in Table 5 .

Table 5. Permeability values for each surface after 10 years of operation.

\begin{tabular}{ccccc}
\hline \multirow{2}{*}{ Test Used } & \multicolumn{4}{c}{ Average Permeability (mm/h) } \\
\cline { 2 - 5 } & $\begin{array}{c}\text { PMPC } \\
\text { (9 bays) }\end{array}$ & $\begin{array}{c}\text { PA } \\
\text { (9 bays) }\end{array}$ & $\begin{array}{c}\text { ICBP-1 } \\
\text { (10 bays) }\end{array}$ & $\begin{array}{c}\text { ICBP-2 } \\
\text { (9 bays) }\end{array}$ \\
\hline NLT-327/00 & $<5-10 \mathrm{~mm} / \mathrm{h}$ & $<5-10 \mathrm{~mm} / \mathrm{h}$ & - & - \\
C1701/1701M-09 & $<5-10 \mathrm{~mm} / \mathrm{h}$ & $<5-10 \mathrm{~mm} / \mathrm{h}$ & - & - \\
C1781/C1781M-15 & - & - & 2872 & 16,510 \\
\hline
\end{tabular}

\subsection{End of Life Analysis}

PMPC and PA surfaces entirely lost their infiltration capacity after 10 years due to a combination of sediment clogging, traffic load, and design-related decisions such as described in Section 2.2. These surfaces have been reported to cope with $2000 \mathrm{~g} / \mathrm{m}^{2}$ of sediment [15]. Therefore, a sediment ratio can be estimated to be around $200 \mathrm{~g} / \mathrm{m}^{2}$ year for this experimental site. It is necessary to remark that, due to the singular design of this car park, impervious surfaces within the car park did not contribute runoff to the permeable pavement. However, there was an important contribution from nearby areas due to sediment blown in by the wind in the city of Santander, which has been reported by [32] to include a high percentage of fine metal sediment from industrial sources. In addition, visual evidence of clogging was found in both porous-mixture surfaces. The NLT-327/00 test cannot perform correctly under nearly clogged or completely clogged surface conditions due to its lack of waterproofing materials around the bottom perimeter of the LCS permeameter. Water was observed to run off from the LCS during the tests at 10 years. Therefore, ASTM C1701/1701M-09 was additionally performed in order to confirm that the visual inspection was correct and that both surfaces had lost their capacity to infiltrate (Table 4), reaching the "end-of-life" scenario regarding their hydrological performance.

ICBP shows a different hydrological performance than the porous mixtures. ICBP- 1 lost $69 \%$ of its infiltration capacity over 10 years. However, it presented a high permeability rate in comparison with other studies such as [33], which found values of permeability near $2000 \mathrm{~mm} / \mathrm{h}$ in a car park in North Carolina with the presence of fine sediment. North Carolina has similar climatic conditions to Northern Spain in terms of average annual rainfall and average temperature. Furthermore, the experimental site of this study is located near beaches and wind also contributes to the deposition of particles from vehicular traffic, as happened in the North Carolina site. The presence of fine sediment in the car park has been demonstrated by the loss of permeability in both porous mixtures, which are preferentially clogged by fine sediment [34]. In the case of ICBP-2, the permeability was even 
higher, reaching values comparable to those previously found in car parks without the presence of fine sediment $(>10,000 \mathrm{~mm} / \mathrm{h})$ [33]. This scenario can be explained due to the fact that ICBP-2 can cope with $4000 \mathrm{~g} / \mathrm{m}^{2}$, as reported by [35], which, together with its high volume between paving units and the lack of aggregates there, increments the capacity to infiltrate and maintain high permeability rates after 10 years of operation with no maintenance.

Furthermore, grass growth was observed to occur in the joints between impervious and permeable areas when using ICBP surfaces, marking areas with lesser permeability in those surfaces. Nevertheless, the main reason for clogging near these areas is traffic load and the metallic plate used in the joints between car park bays and impervious and permeable areas with produced visible steps.

Trend lines for the reduction in permeability for each PPS surface be seen in Figure 6 and Table 6. Also, the range of time when each surface reaches 0 permeability can be seen in Table 6 .

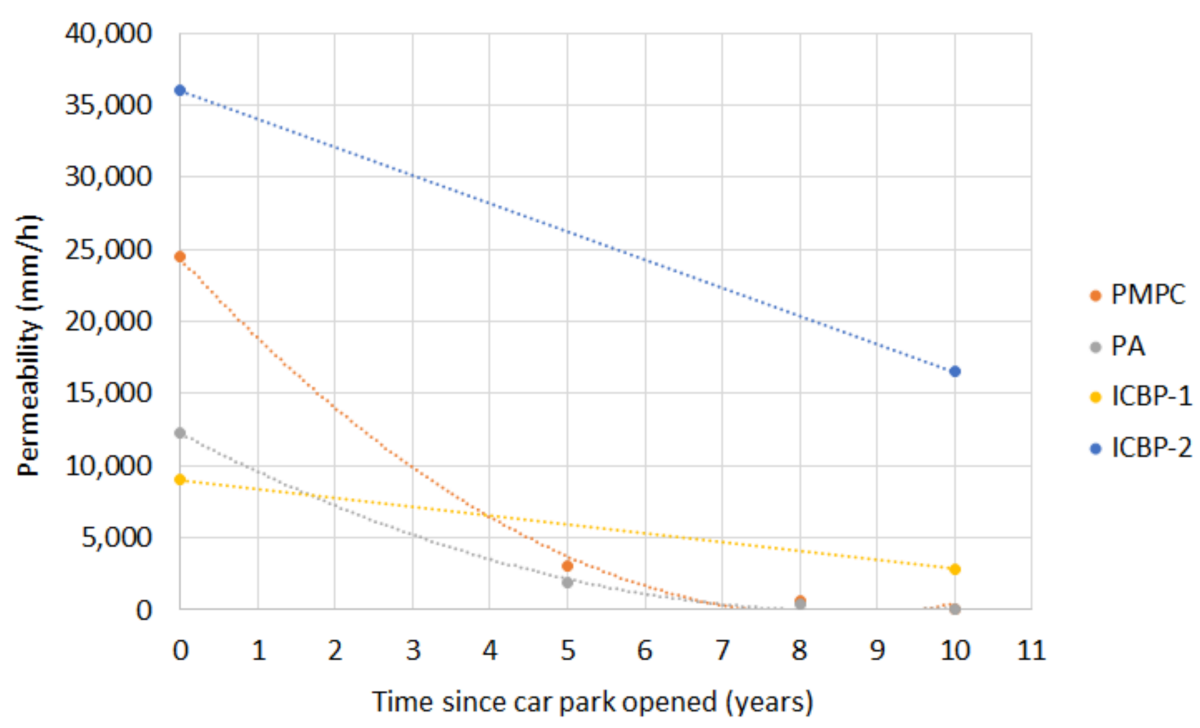

Figure 6. Evolution and trend lines for the permeability depending upon the PPS surface.

Porous-mixture surfaces presented less resilience to clogging than ICBP surfaces in all cases (Figure 6). For instance, PA presented a lower infiltration capacity than the ICBP-1 surface after 2 years since the car park was opened and with no maintenance. However, PMPC kept higher values of permeability than the ICBP-1 surface until four years. In conclusion, porous mixtures provided a high permeability rate over the first four years and became less competitive than the ICBP-1 surface after that time with no maintenance. On the contrary, ICBP-2 showed better permeability than both porous-mixture surfaces since the beginning of its operational life.

Table 6. Trends for the loss of permeability on each PPS surface.

\begin{tabular}{ccc}
\hline Type of Surface & Equation & Range of Time to Reach 0 Permeability (years) \\
\hline PMPC & $\mathrm{y}=348,32 \mathrm{x}^{2}-5874.3 \mathrm{x}+24,366$ & $7-8$ \\
PA & $\mathrm{y}=163,45 \mathrm{x}^{2}-2839.9 \mathrm{x}+12,260$ & $7-8$ \\
ICBP-1 & $\mathrm{y}=-612.8 \mathrm{x}+9000$ & $14-15$ \\
ICBP-2 & $\mathrm{y}=-1949 \mathrm{x}+36,000$ & $18-19$ \\
\hline
\end{tabular}

This experimental car park had no maintenance during its operational life; therefore, these data are of great value to identify when maintenance should be carried out for each type of PPS surface. The sediment contribution processes mentioned previously also add important information about the potential limitation of this study. These results indicate that both PA and PMPC surfaces would need to be maintained before reaching seven years after installation in the field for a car park with contribution 
of fine sediment and the specific climatic and construction conditions of this car park. In the case of the ICBP-1 surface, this range goes further, nearly doubling the time for the porous-mixture surfaces to become clogged, going up to 14 years since construction and opening.

Finally, ICBP-2 would go even further down the line. However, there are no initial values of permeability that allow us to determine a trend for their loss of permeability, highlighting another limitation from this study that will need further attention from other researchers and practitioners in the future. However, it is known that these concrete blocks utilised to construct the ICBP-2 surface have a maximum tolerance of $4000 \mathrm{~g} / \mathrm{m}^{2}$ to become clogged, as per the investigation by [34]. Thus, if the PA and PMPC surfaces became clogged after around eight years of operation based on the trend lines obtained in Table 6, and these surfaces can cope with $2000 \mathrm{~g} / \mathrm{m}^{2}$, the sediment ratio would increase from the previously estimated $200 \mathrm{~g} / \mathrm{m}^{2}$ year to $250 \mathrm{~g} / \mathrm{m}^{2}$ year. With this contribution ratio of sediment, the hydrological end of life for the ICBP-2 could be estimated to reach $4000 \mathrm{~g} / \mathrm{m}^{2}$. Sixteen years would be needed to reach that amount of sediment $\left(250 \mathrm{~g} / \mathrm{m}^{2}\right.$ year $)$ and clog the surface with an upper limit time of 20 years in the case of a $200 \mathrm{~g} / \mathrm{m}^{2}$ yearly rate. These estimations confirmed the trend found for ICBP-1, which indicated a minimum of 15 years to reach the hydrological "end-of-life."

\section{Conclusions}

Maintenance activities are of great importance to keep PPS adequately performing their hydrological function of infiltration, as has demonstrated in the case of the experimental car park studied in this research, which underwent no maintenance in the 10 years since it was opened to traffic. The lack of maintenance produced a reduction in the permeability of all PPS due to sediment clogging their surface layer and an initial singular constructive design due to research purposes. This became an important issue after six years of operation in car parks because of conditions like relevant wind speed near the coast, the potential contribution of beach sand and metals from industry, Cfb climatic characteristics and fine sediment, as was the case in Santander, Northern Spain.

The Spanish Standard NLT-327/00, which uses the LCS permeameter, was not conclusive for determining the hydrological "end-of-life" in porous-mixture surfaces due to the lack of sealing at the bottom perimeter of the ring, which allowed water to runoff over the surface. Therefore, the test introduced uncertainty and visual inspection was needed to confirm that water was not infiltrating through the porous surface. The ASTM C1701/C1701M-09 test was also necessary to confirm what was found visually and determine the hydrological "end-of-life."

Trend lines were obtained for all PPS surfaces to describe the loss in permeability since the car park was opened 10 years ago. It is important to note that ICBP surfaces were tested after 10 years using the ASTM standard test and that these data were compared to the initial values provided by industry in both IBP designs. Therefore, further confirmation in the form of future research is recommended in order to provide more accurate trends.

PA and PMPC were the most severely affected surfaces, becoming completely clogged after 10 years of performance based on the standardised tests carried out in this research. Nevertheless, the trend developed based on these results showed that the clogging may have occurred after eight years, as demonstrated by the low values of permeability achieved in the experiments carried out at that time. The final confirmation of this "end-of-life" scenario was obtained after 10 years using a combination of the Spanish and ASTM Standards.

ICBP showed higher resilience and endurance against clogging conditions. Despite suffering an important reduction in permeability after 10 years of operation, they presented a high infiltration rate, as obtained using the ASTM C1781/C1781M-15. ICBP-2 showed the highest permeability ratio of the two ICBP designs investigated due to the larger volume between the paver joints and the lack of aggregates between those joints, which augmented their capacity to receive sediment up to $4000 \mathrm{~g} / \mathrm{m}^{2}$.

Spatial variation in the reduction of the infiltration capacity due to vehicle static loads has been observed in all permeable pavements, becoming significant in PMPC surfaces. Clogging was observed to occur first near the joints between impervious and permeable surfaces. 
Unappropriated constructive design influenced the sediment deposition patterns and therefore the clogging processes in the whole car park. Only sediment blown in by the wind and deposited over the permeable pavement could really be counted as a major contributor to clogging. Also, the vehicle load has been observed to be a major concern in the reduction of the infiltration capacity.

Acknowledgments: The authors would like to thank the City Council of Santander for allowing us to perform the research study and the GITECO Research Group for the development of the experimental car park. Luis A. Sañudo-Fontaneda, Fernando Cadenas-Fernández and Carlos Costales-Campa thank the University of Oviedo for funding the UOStormwater research team, part of the GICONSIME Research Group, through the research project PAPI-17-PEMERG-22, and the IUTA for their support. Valerio C. Andres-Valeri and Iñigo Cabezon-Jimenez also acknowledge the funding from the Spanish ministry of Economy and Competitiveness through the projects SUPRIS-SUReS (BIA2015-65240-C2-1-R) and SUPRIS-SUPel (BIA2015-65240-C2-2-R).

Author Contributions: Luis A. Sañudo-Fontaneda and Valerio C. Andrés-Valeri designed the experiments; Luis A. Sañudo-Fontaneda, Valerio C. Andrés-Valeri, Carlos Costales-Campa, Iñigo Cabezon-Jimenez and Fernando Cadenas-Fernández performed the experiments; Luis A. Sañudo-Fontaneda, Carlos Costales-Campa and Fernando Cadenas-Fernández took the pictures; Carlos Costales-Campa created the infographics for Figure 2; Luis A. Sañudo-Fontaneda and Valerio C. Andrés-Valeri carried out the statistical analyses; Luis A. Sañudo-Fontaneda wrote the paper.

Conflicts of Interest: The authors declare no conflict of interest.

\section{References}

1. Fletcher, T.D.; Shuster, W.; Hunt, W.F.; Ashley, R.; Butler, D.; Arthur, S.; Trowsdale, S.; Barraud, S.; Semadeni-Davies, A.; Bertrand-Krajewski, J.-L.; et al. SUDS, LID, BMPs, WSUD and more-The evolution and application of terminology surrounding urban drainage. Urban Water J. 2015, 12, 525-542. [CrossRef]

2. Nnadi, E.O.; Coupe, S.J.; Sañudo-Fontaneda, L.A.; Rodriguez-Hernandez, J. An evaluation of enhanced geotextile layer in permeable pavement to improve stormwater infiltration and attenuation. Int. J. Pavement Eng. 2014, 15, 925-932. [CrossRef]

3. Castro-Fresno, D.; Andrés-Valeri, V.C.; Sañudo-Fontaneda, L.A.; Rodriguez-Hernandez, J. Sustainable drainage practices in Spain, specially focused on pervious pavements. Water (Switz.) 2013, 5, 67-93. [CrossRef]

4. Jato-Espino, D.; Sañudo-Fontaneda, L.A.; Andrés-Valeri, V.C. Green Infrastructure: Cost-Effective Nature-Based Solutions for Safeguarding the Environment and Protecting Human Health and Well-Being. In Handbook of Environmental Materials Management, 1st ed.; Hussain, C., Ed.; Springer: Cham, Switzerland, 2018; ISBN 78-3-319-58538-3.

5. Stormwater Design Manual. North Carolina Department of Environmental Quality. Available online: https:/ / deq.nc.gov/sw-bmp-manual (accessed on 28 February 2018).

6. Woods Ballard, B.; Wilson, S.; Udale-Clarke, H.; Illman, S.; Scott, T.; Ashley, R.; Kellagher, R. The SuDS Manual; CIRIA: London, UK, 2015; p. 968, ISBN 979-0-86017-760-9.

7. Sañudo Fontaneda, L.A. The Analysis of Rainwater Infiltration into Permeable Pavements, with Concrete Blocks and Porous Mixtures, for the Source Control of Flooding. Ph.D. Thesis, University of Cantabria, Santander, Spain, 10 June 2014. Available online: https: / / repositorio.unican.es/xmlui/handle/10902/5053 (accessed on 28 February 2018).

8. Nichols, P.W.B.; Lucke, T. A Detailed Analysis of Sediment Particle Sizes and Clogging in Permeable Pavements. Clean Soil Air Water 2017, 45, 1700078. [CrossRef]

9. Lucke, T.; Beecham, S. Field investigation of clogging in a permeable pavement system. Build. Res. Inf. 2011, 39, 603-615. [CrossRef]

10. Rodriguez-Hernandez, J.; Castro-Fresno, D.; Fernández-Barrera, A.H.; Vega-Zamanillo, Á. Characterization of Infiltration Capacity of Permeable Pavements with Porous Asphalt Surface Using Cantabrian Fixed Infiltrometer. J. Hydrol. Eng. 2012, 17, 597-603. [CrossRef]

11. McLaughlin, A.-M.; Charlesworth, S.; Coupe, S.; de Miguel, E. Resilience and sustainable drainage: End-of-life. In Proceedings of the 9th International Conference Novatech, Lyon, France, 28 June 2016; ISBN 978-2-917199-06-0. 
12. Li, H.; Kayhanian, M.; Harvey, J.T. Comparative field permeability measurement of permeable pavements using ASTM C1701 and NCAT permeameter methods. J. Environ. Manag. 2013, 118, 144-152. [CrossRef] [PubMed]

13. Al-Rubaei, A.M.; Stenglein, A.L.; Viklander, M.; Blecken, G.T. Long-Term hydraulic performance of porous asphalt pavements in Northern Sweden. J. Irrig. Drain. Eng. 2013, 139, 499-505. [CrossRef]

14. Fernández-Barrera, A.H.; Castro-Fresno, D.; Rodríguez-Hernández, J.; Calzada-Pérez, M.A. Infiltration capacity assessment of urban pavements using the LCS permeameter and the CP infiltrometer. J. Irrig. Drain. Eng. 2008, 134, 659-665. [CrossRef]

15. Sañudo-Fontaneda, L.A.; Rodriguez-Hernandez, J.; Calzada-Pérez, M.A.; Castro-Fresno, D. Infiltration behaviour of Polymer-Modified Porous Concrete and Porous Asphalt surfaces used in SUDS techniques. Clean Soil Air Water 2013, 42, 139-145. [CrossRef]

16. Essenwanger, O.M. General Climatology 1C: Classification of Climates; Elsevier Science: Amsterdam, The Netherlands, 2001; pp. 1-102.

17. Sañudo-Fontaneda, L.A.; Charlesworth, S.M.; Castro-Fresno, D.; Andres-Valeri, V.C.A.; Rodriguez-Hernandez, J. Water quality and quantity assessment of pervious pavements performance in experimental car park areas. Water Sci. Technol. 2014, 69, 1526-1533. [CrossRef] [PubMed]

18. García Couto, M.A. Iberian Climate Atlas Air Temperature and Precipitation (1971-2000); Instituto de Meteorologia de Portugal; Agencia Estatal de Meteorología y Ministerio de Medio Ambiente y Medio Rural y Marino del gobierno de España: Madrid, Spain, 2011; ISBN 978-84-7837-079-5.

19. Sañudo-Fontaneda, L.A.; Andrés-Valeri, V.C.A.; Rodriguez-Hernandez, J.; Castro-Fresno, D. Field study of infiltration capacity reduction of porous mixture surfaces. Water (Switz.) 2014, 6, 661-669. [CrossRef]

20. European Standard EN 12390-1, Testing Hardened Concrete-Part 1: Shape, Dimensions and other Requirements for Specimens and Moulds; European Committee for Standardization: Brussels, Belgium, 2012.

21. European Standard EN 12390-2, Testing Hardened Concrete-Part 2: Making and Curing Specimens for Strength Tests; European Committee for Standardization: Brussels, Belgium, 2009.

22. European Standard EN 12390-3, Testing Hardened Concrete-Part 3: Compressive Strength of Test Specimens; European Committee for Standardization: Brussels, Belgium, 2009.

23. Pindado, M.Á.; Aguado, A.; Josa, A. Fatigue behavior of polymer-modified porous concretes. Cem. Concr. Res. 1999, 29, 1077-1083. [CrossRef]

24. European Standard EN 933-1. Ensayos Para Determinar Las Propiedades Geométricas de los Áridos. Parte 1: Determinación de la Granulometría de las Partículas, Método del Tamizado; AENOR: Madrid, Spain, 2012.

25. Bustos, G.; Pérez, E. Pliego de Prescripciones Técnicas Generales Para Obras de Carreteras y Puentes, 5th ed.; Ediciones LITEAM: Madrid, Spain, 2007.

26. BS EN 1338:2003. Concrete Paving Blocks-Requirements and Test Methods; European Committee for Standardization: Brussels, Belgium, 2003.

27. NLT-327/00. Permeabilidad in Situ de Pavimentos Drenantes Con el Permeámetro LCS; Gabinete de Formación y Documentación; Centro de Estudios y Experimentación de Obras Públicas (CEDEX): Madrid, Spain, 1996.

28. European Standard EN 12697-40, Bituminous Mixtures-Test Methods for Hot Mix Asphalt-Part 40: In Situ Drainability; European Committee for Standardization: Brussels, Belgium, 2012.

29. ASTM C1701/C1701M-17a. Standard Test Method for Infiltration Rate of In Place Pervious Concrete; ASTM International: West Conshohocken, PA, USA, 2017. [CrossRef]

30. ASTM C1781/C1781M-15. Standard Test Method for Surface Infiltration Rate of Permeable Unit Pavement Systems; ASTM International: West Conshohocken, PA, USA, 2015. [CrossRef]

31. Pérez Jiménez, F.E.; Calzada Pérez, M.A. Analysis and Evaluation of the Performance of Porous Asphalt: The Spanish Experience. Surface characteristics of roadways: International research and technologies. In Proceedings of the First International Symposium on Surface Characteristics, Pennsylvania, PA, USA, 8-9 June 1988; ASTM STP 1031. Reichert, M., Ed.; ASTM: West Conshohocken, PA, USA, 1988.

32. Arruti, A.; Fernández-Olmo, I.; Irabien, A. Evaluation of the contribution of local sources to trace metals levels in urban PM2.5 and PM10 in the Cantabria region (Northern Spain). J. Environ. Monit. 2010, 12, 1451-1458. [CrossRef] [PubMed]

33. Bean, E.Z.; Hunt, W.F.; Bidelspach, D.A. Field survey of permeable pavement surface infiltration rates. J. Irrig. Drain. Eng. 2007, 133, 249-255. [CrossRef] 
34. Andrés-Valeri, V.C.; Marchioni, M.; Sañudo-Fontaneda, L.A.; Giustozzi, F.; Becciu, G. Laboratory assessment of the infiltration capacity reduction in clogged porous mixture surfaces. Sustainability (Switz.) 2016, 8, 751. [CrossRef]

35. Sañudo-Fontaneda, L.A.; Rodriguez-Hernandez, J.; Vega-Zamanillo, A.; Castro-Fresno, D. Laboratory analysis of the infiltration capacity of interlocking concrete block pavements in car parks. Water Sci. Technol. 2013, 67, 675-681. [CrossRef] [PubMed] 